\title{
Quantitative noise analysis at two marble finishing plants in Olinda, Pernambuco, Brazil
}

Melo Neto, Rútilo P. de ${ }^{a}$; Kohlman Rabbani, Emilia R. ${ }^{b}$, Barkokébas Junior, Béda ${ }^{c}$; Lago, Eliane M. G. ${ }^{d}$ and Freitas, Jonathas B. de A. ${ }^{e}$

\author{
${ }^{a}$ Specialist in Occupational Safety Engineering, UPE/POL, Recife, Pernambuco, Brasil. \\ rutilo@br.inter.net \\ ${ }^{b}$ Adjunct Lecturer, UPE/POLI/PEC/LSHT. \\ ${ }^{c}$ Adjunct Lecturer, UPE/POLI/PEC/LSHT. \\ ${ }^{d}$ Assistant Lecturer, UPE/POLI/LSHT. \\ ${ }^{e}$ Graduate Student in Civil Engineering, UPE/POLI.
}

\begin{abstract}
In Olinda there are an estimated 50 marble quarries, 3 of which are members of the stone extraction and finishing industry's state union. The objective here is to quantitatively evaluate the noise present at the workplace in two of Olinda's unionized marble quarries. The data to be analyzed was collected during December 2010, this month representing one of the four busiest months of production. The samples were collected from Tuesdays to Fridays in order to avoid irregular outcomes. Instantaneous readings were taken with the decibel meter to identify points of Noise Pressure Level (NPL) higher than Action Level (AL). Afterwards, the full procedure for the characterization of noise level with the decibel meter in order to compare the Homogeneous Exposure Group (HEG) to those with High Risk Exposure (HRE) was initiated. The noisiest sources came from humid cutting machines, marble saws and polishing equipment. The activities of cutter and polisher became classified as follows: unsafe, in a critical situation and in need of priority control for the work environment with noise level values varying from $95.0 \mathrm{~dB}(\mathrm{~A})$ to 103.3 $\mathrm{dB}(\mathrm{A})$, calling for the use of ear protection during the entire work day.
\end{abstract}

Keywords: Exposure to occupacional noise. Occupacional health. Marble works

\section{Introduction}

Seventy percent of the territory of the State of Pernambuco is formed by rocks of Precambrian crystalline base, whose associated litho-structural characteristics are considered excellent in aesthetic and decorative terms (VIDAL; CASTRO, 2008).

Olinda has an estimated total of 50 marble finishing plants, of which three are effectively included in the state mining and stone-processing union. (SINDIPEDRA, 2010).

Finishing of stone for the production and supply of ornamental artifacts takes place in marble quarries. The products are especially suitable for civil construction projects.

Marble finishing plants are an important productive sector in the State of Pernambuco and there are many associated hazards, as evident in the qualitative assessment of risks developed by Melo Neto and Kohlman Rabbani in 2011. This has identified, through the technique of preliminary risk analysis, noise as an occupational hazard in the marble finishing plant environment.

The objective of this study is to quantitatively evaluate the noise present at the various work spots within two unionized marble finishing plants in Olinda.

\section{Methodology}

The methodology for assessing occupational noise aims to recognize the target hazard areas during the activities executed in marble quarries - in other words, areas where the activities performed have exceeded the action level. The techniques used observe NR 15 and the procedures of the NHO 01 (FUNDACENTRO, 2001). The tolerance limits considered were as set out in Annex No. 1 of NR-15 (BRAZIL, 2010) and the action level considered was established by NR 9 .

In order to measure continuous and intermittent noise in the two marble quarries, Homogeneous Exposure Groups (HEG) were characterized, and those with High Risk Exposure (HRE) were considered in their normal workday routine on previously determined days. For this, readings were made using the weighted curve "A" and the slow response curve for continuous noise within the workers' hearing threshold, and then compared with the limits of noise pollution tolerance established by Brazilian legislation.

The equipment utilized to measure industrial noise were the digital decibel meter, the Quest brand audio dosimeter (both calibrated), and accessories, all given by the Occupational Safety Laboratory (LSHT) at the Polytechnical University of Pernambuco (POLI / UPE) for the development of field research. 
Samples were collected during the month of December 2010 , as this is one of the four months where marble production operates at an increased level. Collection took place from Tuesdays to Fridays. Mondays and Saturdays were not included because of reduced operation on those days at both of the marble finishing plants studied.

At first instantaneous measurements were taken with the decibel meter in order to map noise in the production areas. This information was used to find the areas of greatest machine and equipment noise.

After identifying locations having a Noise Pressure Level (NPL) higher than the action level (AL), the complete procedure for measuring the level of noise using dosimetry was begun for each HEG using the HRE.

Figure 1 shows the layouts of the marble finishing plants and illustrates the work areas selected for quantitative evaluation.

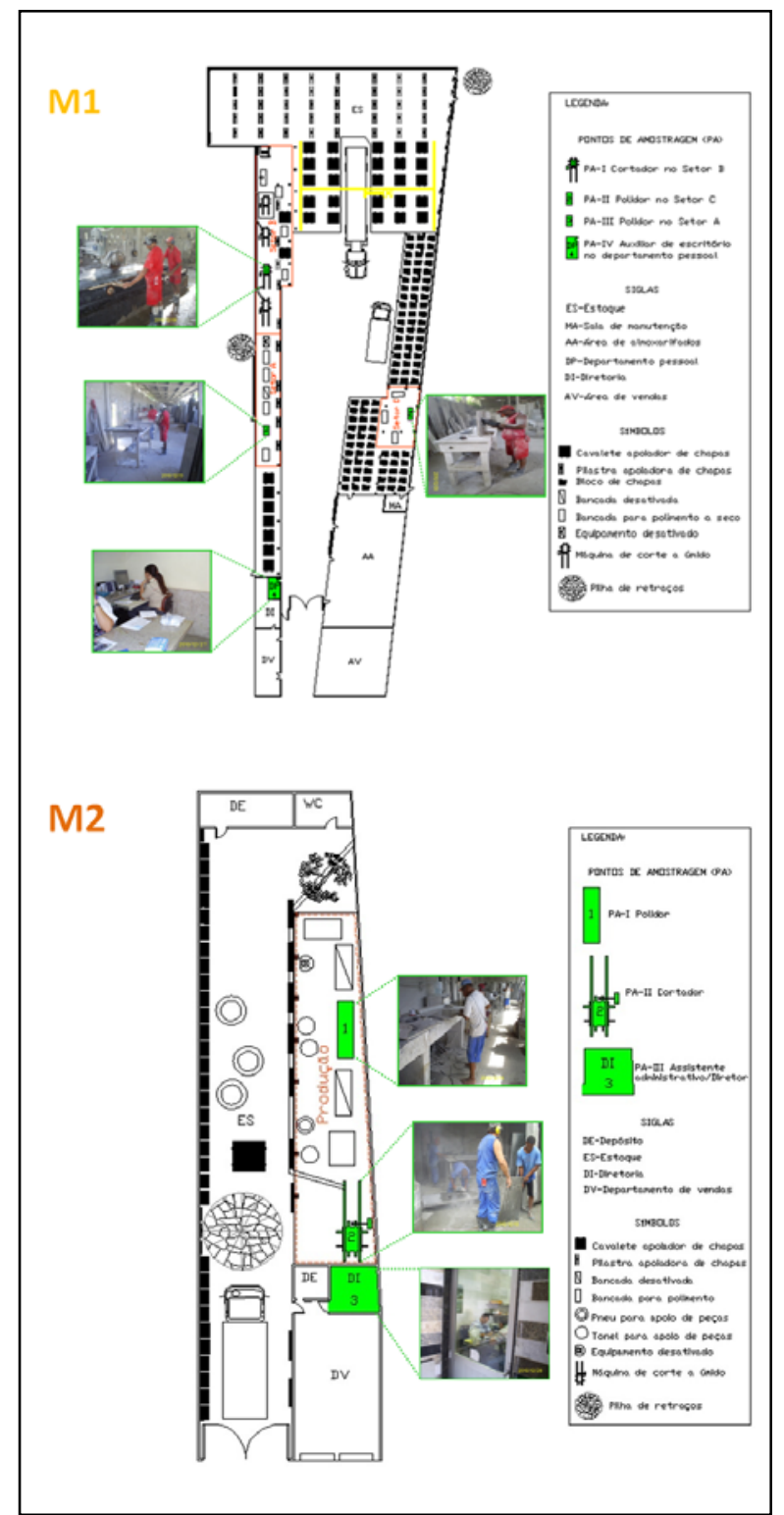

Figure 1 - Floor plan of marble finishing plants M1 and M2 highlighting areas of dosimetry sampling.

\section{Results}

Quantitative evaluation revealed that the Action Level was exceeded, extending itself to the surroundings of the production area in both marble finishing plants.

The worst noise sources found while monitoring the work environment during the production process were the wet saws, marble saws, and sanders.

Table 1 presents a summary of the principal data collected by dosimeter through the equivalent continuous noise level (LEQ or LAVG) with the respective level of noise attenuated by ear protection $\left(\mathrm{NPS}_{\mathrm{sf}}\right)$. The $\mathrm{NPS}_{\mathrm{sf}}$ signifies a "mean value" offered by the individual ear protection's (EPI) certificate of approval (CA) to be subtracted from the "average" noise of the environment (LAVG in the table). In this way one obtains the effective deadening of noise inside the ear whilst protection is in use $\left(\mathrm{NPS}_{\mathrm{c}}\right)$. This methodology is from the Shortened Method (EN 458, 2004) which creates a direct relationship with the efficiency of the protector's attenuation during its time in use. For example, if during a day of work lasting 8 hours the individual ear protection (EPI) is used for 7.5 hours, the attenuation is reduced to $40 \%$ of the maximum attenuation furnished by the certificate of approval; in the case of 4.0 hours of use, the effective attenuation given through ear protection is only $10 \%$ of the maximum.

Table 1

Dosimeter results and noise attenuation for the high risk group within the Homogeneous Exposure Group (GHE) by sample/location in Marble Quarries M1 and M2.

\begin{tabular}{|c|c|c|c|c|c|c|c|c|}
\hline \multirow{4}{*}{ Puatoderasosngen } & \multirow{4}{*}{ GEII } & \multirow{4}{*}{ dtribde Fuxio } & \multicolumn{2}{|c|}{$\begin{array}{c}\text { Cospuntio } \\
\text { do } \\
\text { Virdegurieate Dose }\end{array}$} & \multirow{2}{*}{\multicolumn{4}{|c|}{ 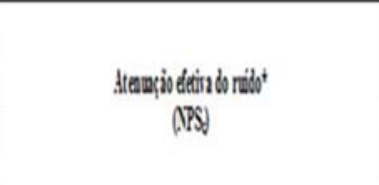 }} \\
\hline & & & \multirow{3}{*}{ 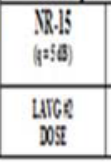 } & \multirow{3}{*}{ 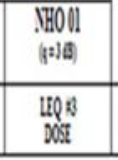 } & & & & \\
\hline & & & & & & $\mathrm{ch}^{\mathrm{t}}$ & $\mathrm{Pls}$ & $a e^{i+i}$ \\
\hline & & & & & $\mathbb{W}_{\mathrm{d}}$ & W & $\mathbb{W}_{\mathrm{f}}$ & $\mathrm{NB}_{\mathrm{Z}}$ \\
\hline \multicolumn{9}{|c|}{ MI } \\
\hline Produchlo (Setor A) & 5 & Polidor & $\begin{array}{r}102,0 \mathrm{~dB}(A) \\
1.057,2 \%\end{array}$ & $\begin{array}{r}105,3 \mathrm{~dB}(\mathrm{~A}) \\
10.603,8 \%\end{array}$ & $1,4 \mathrm{AB}(A)$ & $100,6 \mathrm{~dB}(\mathrm{~A})$ & $1,6 \mathrm{~dB}(\mathrm{~A})$ & $100,4 \mathrm{~dB}(\mathrm{~A})$ \\
\hline \multicolumn{9}{|c|}{ MI } \\
\hline Produça (Setot B) & 10 & Cortador & $\begin{array}{l}96,7 \mathrm{~dB}(\mathrm{~A}) \\
508,9 \%\end{array}$ & $\begin{array}{r}101,2 \mathrm{~dB}(\mathrm{~A}) \\
4.163,9 \%\end{array}$ & $5,6 \mathrm{~dB}(\mathrm{~A})$ & $91,1 \mathrm{~dB}(\mathrm{~A})$ & $6,4 \mathrm{~dB}(\mathrm{~A})$ & $90,3 \mathrm{~dB}(\mathrm{~A})$ \\
\hline \multicolumn{9}{|c|}{ MI } \\
\hline Producho (Setot C) & 4 & Polidor & $\begin{array}{r}95,0 \mathrm{~dB}(A) \\
402,2 \%\end{array}$ & $\begin{array}{l}99,0 \mathrm{~dB}(\mathrm{~A}) \\
2520,3 \%\end{array}$ & $1,4 \mathrm{~dB}(\mathrm{~A})$ & $93,6 \mathrm{~dB}(\mathrm{~A})$ & $1,6 \mathrm{~dB}(\mathrm{~A})$ & $93,4 \mathrm{~dB}(\mathrm{~A})$ \\
\hline $\begin{array}{c}\text { MI } \\
\text { Departamento } \\
\text { pesioal (DP) }\end{array}$ & 2 & $\begin{array}{l}\text { Auxiliar de } \\
\text { escritónio }\end{array}$ & $\begin{array}{c}73,3 \mathrm{~dB}(\mathrm{~A}) \\
19,7 \%\end{array}$ & $\begin{array}{c}84,9 \mathrm{~dB}(\mathrm{~A}) \\
98,2 \%\end{array}$ & \multicolumn{4}{|c|}{$\begin{array}{l}\text { Posto de trabalho com exposichlo ao ruido abaixo do } \\
\text { NA pela legislaflo vigente (NR-15) }\end{array}$} \\
\hline $\begin{array}{c}\text { M2 } \\
\text { Produçio }\end{array}$ & 2 & Polidor & $\begin{array}{l}97,0 \mathrm{~dB}(\mathrm{~A}) \\
528,0 \%\end{array}$ & $\begin{array}{c}100,0 \mathrm{~dB}(A) \\
3.128,2 \%\end{array}$ & & EPI nlo contin & inha o $\mathrm{CA}$ & \\
\hline $\begin{array}{c}\text { M2 } \\
\text { Produeflo }\end{array}$ & 4 & Cortador & $\begin{array}{l}103,3 \mathrm{~dB}(\mathrm{~A}) \\
1.262,6 \%\end{array}$ & $\begin{array}{c}106,7 \mathrm{~dB}(A) \\
14816,7 \%\end{array}$ & & EPI nlo contin & nha o $\mathrm{CA}$ & \\
\hline $\begin{array}{c}\text { M2 } \\
\text { Administrativo } \\
\text { Diroçlo (DI) }\end{array}$ & 3 & Diretor & $\begin{array}{r}77,5 \mathrm{~dB}(A) \\
35,1 \%\end{array}$ & $\begin{array}{c}87,9 \mathrm{~dB}(\mathrm{~A}) \\
193,1 \%\end{array}$ & $\begin{array}{l}\text { Posto de tr: } \\
\text { NA pela ley }\end{array}$ & $\begin{array}{l}\text { abalho com exp } \\
\text { islaç3o vigente }\end{array}$ & (NR-15) & do abaixo do \\
\hline
\end{tabular}


* Workers at M1 and M2: cutters with 7.5 hours per day; polishers with 4 hours per day (The workers use simple protection, some with shell protection, others with plugs).

$* *$ AGENA brand, CA 4398 with maximum attenuation: $\mathrm{NRR}_{\mathrm{sf}}=14$ $\mathrm{dB}(\mathrm{A})$

* * * VONDER brand, CA 11512 with maximum attenuation: $\mathrm{NRR}_{\mathrm{sf}}=16 \mathrm{~dB}(\mathrm{~A})$

The activities of cutter and polisher became classified as follows: unsafe, in a critical situation and in need of priority control for the work environment with noise level values varying from $95.0 \mathrm{~dB}(\mathrm{~A})$ to $103.3 \mathrm{~dB}(\mathrm{~A})$, calling for the use of ear protection during the entire work day. At both locations, the administrative sectors showed noise levels below the action level, with noise equivalent level values of less than $77.5 \mathrm{~dB}(\mathrm{~A})$.

\section{Recommendations}

The study determined that in the two marble finishing plants, noise in some basic work activities was above the NPL permitted by law, and could cause damage to workers' health if appropriate protective measures were not taken. It is expected that the technical inputs provided during quantitative assessments of industrial noise contribute to the establishment of measures for ongoing monitoring. The resulting interest in individual and collective protection will enable the development of OSH management models to ensure quality of life for workers in this productive sector.

\section{References}

[1] Brasil. Ministério do Trabalho. Normas regulamentadoras. Available at:

$<$ http://portal.mte.gov.br/legislacao/normasregulamentadoras.htm> Accessed on: 22/12/2010.

[2] Fundacentro. Fundação Jorge Duprat Figueiredo de Segurança e Medicina do Trabalho. NHO 01: Avaliação de exposição ocupacional ao ruído . São Paulo, 2001.

[3] Melo Neto, R. P. de; Kohlman Rabbani. E. R. Aplicação da análise preliminar de riscos e análise quantitativa do ruído em duas marmorarias da região metropolitana do Recife. Pernambuco, 2011. Monografia (Especialização). Universidade de Pernambuco.

[4] Sindipedra. Cartilha do sindicato da indústria de extração e beneficiamento de pedras do Estado de PE, Recife, 2010.

[5] Vidal, F. W. H.; Castro, N. F. Rochas Ornamentais do Nordeste. In: III Congresso Brasileiro de rochas ornamentais e VI Simpósio de rochas ornamentais do nordeste. Anais.... Rio de Janeiro: $\quad$ CETEM/MCT, 2008. 